Joanna Miniszewska*

Joanna Paul-Kańska**

Anna Zalewska-Janowska***

*Instytut Psychologii UŁ

** Zakład Nauk Humanistycznych PŁ, INDEX Sp. z o.o.

*** Zakład Psychodermatologii, Katedra Immunologii Klinicznej i Mikrobiologii UM w Łodzi

\title{
Akceptacja przewlekłej choroby somatycznej (na przykładzie chorych na łuszczycę i astmę) \\ Czy przekonanie o posiadaniu wpływu na własne zdrowie zawsze pomaga?
}

\section{Wprowadzenie}

Wystapienie każdej przewlekłej choroby i jej leczenie stawia przed chorym niezwykle trudne zadanie - konieczność przystosowania się do wymagań i ograniczeń, jakie ze sobą niesie. Zmaganie się z chorobą można określić jako „proces obejmujący całokształt działań nakierowanych na wyleczenie lub złagodzenie występujących u niej [osoby] objawów oraz obniżenie ryzyka pojawienia się skutków negatywnych w różnych obszarach funkcjonowania człowieka" (Steuden, 2002, s. 31). W miarę postępu choroby przewlekłej zmieniają się procesy radzenia sobie.

$\mathrm{W}$ procesie zmagania się $\mathrm{z}$ chorobą można wyodrębnić kilka kluczowych etapów psychologicznego przystosowania się do choroby, mianowicie: niepewność, zakłócenie równowagi, dążenie do zmiany, powrót do dobrego samopoczucia (J. Morse, J. Johnson za: S te u d en, 2002). Można również wyróżnić dwie formy przystosowania się do choroby, $\mathrm{tj}$. utożsamianie się z chorobą, która wymaga leczenia, oraz świadomość jej istnienia bez etykietowania siebie w związku z tym. Pierwsza łączy się z doświadczaniem takich emocji jak: depresja, załamanie psychiczne, poczucie bezradności i beznadziejności, zwątpienie oraz z uruchomieniem mechanizmów obronnych osobowości. Druga z kolei - mobilizuje do aktywności i radzenia sobie z chorobą niezależnie od jej typu, zaawansowania, zmienności objawów i przewidywanych następstw. Za najistotniejszy czynnik w procesie adaptacji do choroby można uznać akceptację stanu chronicznego i związanych z nim ograniczeń (S t e u d e n, 2002).

W literaturze przedmiotu podkreśla się, że przystosowanie się pacjenta do przewlekłej choroby jest skomplikowanym procesem, na który wpływają 
zarówno wzajemnie oddziaływujące uwarunkowania zewnętrzne (wsparcie społeczne, sytuacja życiowa), jak i właściwości jednostki (m. in. cechy osobowościowe, mechanizmy obronne, system przekonań, sposoby radzenia sobie ze stresem). Przystosowanie się pacjenta do przewlekłej choroby zależy oczywiście również od dynamiki obrazu klinicznego, stopnia zaawansowania choroby, efektów leczenia i rokowania (S c h a r 1 o o i in., 2000; S t e u d e n, 2002).

Dobre przystosowanie się do choroby wyraża się więc $\mathrm{w}$ jej akceptacji (Ju c z yń s k i, 2001; S te u d en, 2002; C h o d k i ew i c z, 2004). Wiąże się ona z uznaniem przez pacjenta faktu wystapienia choroby, swoistą „zgodą" na związane $\mathrm{z}$ nią zmiany $\mathrm{w}$ dotychczasowym życiu (ograniczenia narzucone przez stan fizyczny, uświadomienie konieczności częstych zabiegów i kontaktów z personelem medycznym, stałe doświadczanie poczucia zagrożenia zdrowia i życia).

Akceptacja choroby jest dla wielu osób problemem, z którym zmagają się przez cały czas jej trwania. Jej brak lub niski poziom prowadzą do niestosowania się do zaleceń lekarzy, prób leczenia się „na własną rękę”, negowania sensu leczenia, a także do większego poczucia dyskomfortu psychicznego (J u c z y ń ski, 2001, Ch odkiew ic z, 2004).

Powyższe problemy odnoszą się zarówno do schorzeń bezpośrednio zagrażających życiu, jak i chorób przewlekłych oraz nawracających. Do często występujących i znacznie utrudniających funkcjonowanie człowieka należą m. in. łuszczyca $i$ astma.

Łuszczyca należy do najczęstszych chorób skóry. Szacuje się, że choruje na nią ok. 2\% populacji na świecie (J a błońs ka, Majewski, 2005). Charakteryzuje się złożoną etiologią, w której istotną rolę odgrywa podłoże genetyczne. Choroba ma przewlekły i nawrotowy przebieg. Charakteryzuje się zwiększoną proliferacją naskórka (polegającą na 8-krotnym skróceniu czasu trwania cyklu komórkowego) i złuszczającymi się wykwitami grudkowymi. Istnieje duża różnorodność obrazu morfologicznego i nasilenia zmian, od nielicznych ognisk, ograniczonych do szczególnych okolic, aż do ciężkich postaci zajmujących całą skórę i stawy, a nawet prowadzących do inwalidztwa. W prowokowaniu schorzenia istotny wpływ odgrywają takie czynniki inicjujące, jak: uszkodzenia skóry, infekcje, niektóre leki oraz stres (Pacan i in., 2002; Jabłońska, Majew ski, 2005). Zależności między stresem a łuszczycą są złożone. Stres może wyzwalać wystąpienie, nawrót bądź zaostrzenie zmian chorobowych. Z kolei, objawy choroby mogą być źródłem stresu, który na zasadzie błędnego koła może nasilać objawy (S zumański, Kokoszka, 2001). Łuszczycy najczęściej towarzyszą zaburzenia nastroju. Rozpowszechnienie depresji szacuje się na ok. $57 \%$, natomiast $5 \%$ osób leczonych z powodu łuszczycy podejmuje próbę samobójczą (Cubała i in., 2006). Jak wynika z wielu badań, łuszczyca w znaczny sposób wpływa na jakość życia i co do tego badacze nie mają wątpliwości (Roenigk, Roenigk, 1979; Gins burg, Link, 1989; G in sburg, 1996, McKenna, Stern, 1997; Steuden, Janowski, 2001; 
Papadopoulos, Walker, 2003; Dalgard i in., 2004; Z a chariae i in., 2004; Uttjek i in., 2004; Jankovic i in., 2011). Europejska Federacja Stowarzyszeń Pacjentów z Łuszczycą (European Federation of Psoriasis Patient Associations) przebadała 17990 chorych, z czego aż 77\% deklarowało problemy wynikające ze stanu zdrowia (D u b ert ret i in., 2006).

Astma oskrzelowa jest jedną z najbardziej rozpowszechnionych chorób cywilizacyjnych. Objawia się okresowymi atakami świszczącego oddechu, odczuciem ciężaru w klatce piersiowej, kaszlem i trudnościami z oddychaniem. Przyczyny jej nie są dobrze poznane. Choruje na nią ok. 6\% dorosłej populacji świata. Jest przyczyną ponad 180 tys. zgonów i jedną z niewielu chorób przewlekłych, której wskaźnik umieralności stale wzrasta. Jest przewlekłą chorobą zapalną, o różnych stopniach ciężkości (Światowa strategia..., 2002). Astma oskrzelowa może być przyczyną pogorszenia jakości życia chorego, przy czym dodatkowym niekorzystnym elementem jest jej zmienny przebieg. Chorych na zaawansowaną postać astmy cechuje stałe poczucie zagrożenia kolejnym napadem duszności, co powoduje częstsze występowanie stanów lękowych i depresyjnych (M a n c u s o i in., 2000; A d a m s i in., 2001; Oh, 2008; M o s e n, 2010). Znaczenie czynników emocjonalnych i stopień ograniczenia aktywności społecznej mogą być jednak jeszcze większe, gdy objawy astmy nie są wystarczająco opanowane. Duszność pojawiająca się nieoczekiwanie, napadowo, o dużym nasileniu budzi pogłębiony lęk zarówno poprzez wyobrażenia, takie jak uduszenie się, śmierć, jak i poczucie bezradności oraz beznadziejności. Z kolei silne emocje, lęk i stres zwiększają częstotliwość napadów duszności (Światowa strategia..., 2002).

Celem przeprowadzonych badań było oszacowanie poziomu akceptacji dwóch wybranych schorzeń przewlekłych, różnych pod względem obrazu klinicznego - astmy i łuszczycy - oraz określenie roli przekonania o posiadaniu wpływu na własne zdrowie (zmienna wyjaśniająca) w akceptacji choroby (zmienna wyjaśniana). Uznano, że znajomość zależności między przekonaniami odnośnie do możliwości kontrolowania objawów chorobowych i stopniem akceptacji swojego stanu fizycznego może stać się istotną wskazówką do pracy np. psychoterapeutycznej czy komunikacji lekarz - pacjent z osobami chorymi na astmę lub łuszczycę. W przeprowadzonych analizach uwzględniono również nasilenie objawów chorobowych oraz wybrane zmienne demograficzne.

Stosownie do sformułowanego celu postawiono następujące pytania badawcze.

- Czy chorzy na łuszczycę i chorzy na astmę różnią się poziomem akceptacji swojej choroby?

- Czy przekonanie o posiadaniu lub nieposiadaniu wpływu na własne zdrowie ma związek z akceptacją swojego stanu zdrowia?

- Czy przekonanie o posiadaniu lub nieposiadaniu wpływu na stan swojego zdrowia pozwala przewidywać lepsze przystosowanie się do ograniczeń wynikających ze stanu zdrowia? 
- Czy umiejscowienie kontroli zdrowia odgrywa odmienną rolę w zależności od obrazu klinicznego choroby?

\section{Badane grupy}

Pomiarów dokonano u 120 chorych na łuszczycę w wieku od 17 do 71 lat $(M=39,97 ; S D=12,03)$ i 112 chorych na astmę w wieku od 18 do 69 lat $(M=41,71 ; S D=10,32)$. Średni czas trwania huszczycy to $M=15,49$; $S D=11,67$, średni czas trwania astmy to $M=12,90 ; S D=10,32$. Wśród chorych na łuszczycę najwięcej było mężczyzn z wykształceniem zawodowym, wśród chorych na astmę - mężczyzn z wykształceniem średnim. Charakterystyki obu badanych grup przedstawiono $\mathrm{w}$ tab. 1 .

T a b e la 1

Charakterystyka grupy chorych na łuszczycę i chorych na astmę

\begin{tabular}{|c|c|c|c|c|c|c|}
\hline \multicolumn{7}{|c|}{ Chorzy na łuszczycę } \\
\hline \multirow[t]{2}{*}{ Wiek } & \multicolumn{2}{|c|}{$\begin{array}{l}\text { ogółem } \\
(N=120)\end{array}$} & \multicolumn{2}{|c|}{$\begin{array}{l}\text { kobiety } \\
(N=36)\end{array}$} & \multicolumn{2}{|c|}{$\begin{array}{c}\text { mężczyźni } \\
(N=84)\end{array}$} \\
\hline & $N$ & $\%$ & $N$ & $\%$ & $N$ & $\%$ \\
\hline Do 40 lat & 58 & 48,33 & 11 & 33,33 & 47 & 55,92 \\
\hline Od 41 lat & 62 & 51,67 & 25 & 66,67 & 37 & 44,10 \\
\hline \multicolumn{7}{|c|}{ Wykształcenie } \\
\hline Podstawowe & 28 & 23,33 & 9 & 25,00 & 19 & 22,69 \\
\hline Zawodowe & 50 & 41,66 & 9 & 25,00 & 41 & 48,80 \\
\hline Średnie & 36 & 30,00 & 16 & 44,44 & 20 & 23,80 \\
\hline Wyższe & 6 & 5,00 & 2 & 5,53 & 4 & 4,76 \\
\hline \multicolumn{7}{|c|}{ Chorzy na astmę } \\
\hline \multirow[t]{2}{*}{ Wiek } & \multicolumn{2}{|c|}{$\begin{array}{c}\text { ogółem } \\
(N=112)\end{array}$} & \multicolumn{2}{|c|}{$\begin{array}{l}\text { kobiety } \\
(N=63)\end{array}$} & \multicolumn{2}{|c|}{$\begin{array}{c}\text { mężczyźni } \\
(N=49)\end{array}$} \\
\hline & $N$ & $\%$ & $N$ & $\%$ & $N$ & $\%$ \\
\hline Do 40 lat & 50 & 47,32 & 21 & 33,33 & 29 & 59,18 \\
\hline Od 41 lat & 62 & 64,68 & 42 & 66,67 & 20 & 40,82 \\
\hline \multicolumn{7}{|c|}{ Wykształcenie } \\
\hline Podstawowe & 14 & 12,50 & 15 & 23,80 & 2 & 4,08 \\
\hline Zawodowe & 23 & 20,53 & 28 & 44,00 & 6 & 12,24 \\
\hline Średnie & 53 & 47,33 & 18 & 28,57 & 26 & 53,06 \\
\hline Wyższe & 22 & 19,64 & 2 & 3,17 & 15 & 30,61 \\
\hline
\end{tabular}




\section{Zastosowane metody}

W badaniach wykorzystano następujące metody.

Skala Akceptacji Choroby - AIS (B. Felton, T. Revenson, G. Hinrichsen, polska adaptacja: Z. Juczyński (2001)) do pomiaru stopnia akceptacji choroby. Skala Akceptacji Choroby (Acceptance of Illness Scale), skonstruowana przez B. Felton i in., zawiera 8 stwierdzeń opisujących konsekwencje spowodowane chorobą. Twierdzenia zawarte w skali wyrażają określone trudności i ograniczenia wynikające ze stanu zdrowia. Dotyczą one $\mathrm{m}$. in. poczucia braku samowystarczalności, zależności od innych osób, obniżonego poczucia własnej wartości. Stopień akceptacji choroby przejawia się brakiem negatywnych reakcji i emocji związanych z chorobą. Skala może być wykorzystana do pomiaru akceptacji każdej choroby. Im wynik jest wyższy, tym większa akceptacja swojego stanu i mniej negatywnych emocji związanych $\mathrm{z}$ chorobą. Zarówno $\mathrm{w}$ wersji oryginalnej, jak i polskiej adaptacji skala posiada dobre właściwości psychometryczne. Współczynniki rzetelności wersji polskiej są zbliżone do oryginalnej, dla której $\alpha$-Cronbacha wynosi 0,82 (J uczyński, 2001).

Wielowymiarowa Skala Umiejscowienia Kontroli Zdrowia - MHLC (K. Wallston, B. Wallston, R. Devellis, polska adaptacja: Z. J u czyński (2001)), mierząca przekonania dotyczące zgeneralizowanych oczekiwań w trzech wymiarach umiejscowienia kontroli zdrowia. Skala jest narzędziem samoopisu, składa się $\mathrm{z}$ dwu równoważnych wersji zawierających po 18 stwierdzeń, badających umiejscowienie kontroli zdrowia: 1) wewnętrzne kontrola nad własnym zdrowiem zależy ode mnie; 2) wpływ innych - własne zdrowie jest wynikiem oddziaływania innych, zwłaszcza personelu medycznego; 3) przypadek - o stanie zdrowia decyduje przypadek lub inne czynniki zewnętrzne. Im wyższy wynik, tym silniejsze przekonanie, że dany czynnik ma wpływ na stan zdrowia. Rzetelność obu polskich wersji została sprawdzona za pomocą różnych metod. W próbie 166 dorosłych wskaźnik $\alpha$-Cronbacha dla wersji A wynosi: 0,74 - dla kontroli wewnętrznej, 0,69 - dla przypadku, 0,54dla wpływu innych. W innej próbie (102 osoby) korelacja w skali kontroli wewnętrznej wynosiła 0,60 , dla przypadku $-0,59$, dla skali wpływ innych $-0,68$ (Juczyński, 2001).

Skala PASI - do obiektywnej oceny ciężkości zmian chorobowych w łuszczycy (Fridriks s on, Peters son, 1978; Jan owski, 2006). Skala ta jest powszechnie wykorzystywaną w świecie miarą stanu klinicznego łuszczycy. Ocena jest dokonywana przez lekarza (specjalistę dermatologa) i polega na określeniu stopnia nasilenia zmian skórnych, takich jak rumień, nacieczenie i złuszczanie. Każdą ze zmian ocenia się osobno dla rejonu głowy, tułowia, kończyn górnych i dolnych. Określa się również obszar skóry zajętej procesem chorobowym (osobno dla każdego rejonu ciała). Uzyskaną liczbę punktów mnoży się przez sumę punktów uzyskanych dla poszczególnych cech nasilenia 
zmian chorobowych. Następnie wyniki mnoży się poprzez określone współczynniki i na koniec sumuje wszystkie punkty. Im wynik wyższy, tym większe nasilenie procesu chorobowego. Uzyskane wyniki pozwalają wyróżnić łuszczycę o lekkim, umiarkowanym i ciężkim nasileniu zmian (A kay i in., 2002; Janowski, 2006).

Ciężkość astmy również została oceniona przez lekarza (specjalistę pulmonologa) na podstawie internistycznej klasyfikacj NHLBI/NAEPP (Światowa strategia..., 2002; P oto c zek, 2010). Ciężkość choroby ocenia się na podstawie obrazu klinicznego przed rozpoczęciem leczenia. Uwzględnia się częstość i nasilenie objawów (np. objawy w nocy - częste, częściej niż raz w tygodniu, częściej niż 2 razy w miesiącu, nie częściej niż dwa razy w miesią$\mathrm{cu}$ ), zużycie mimetyku $\beta_{2}$ stosowanego doraźnie oraz, procentowo, obiektywne parametry czynnościowe płuc $\left(\mathrm{FEV}_{1}, \mathrm{PEF}\right.$, dobowa zmienność PEF). Uzyskana ocena pozwala wyróżnić różne stopnie ciężkości, tj. astmę sporadyczną, przewlekłą lekką, przewlekłą umiarkowaną i przewlekłą ciężką.

\section{Wyniki}

Pierwszym etapem analizowania uzyskanych danych było porównanie poziomu akceptacji choroby $\mathrm{w}$ obu grupach. Okazało się, że z ograniczeniami wynikającymi ze stanu zdrowia zdecydowanie lepiej radzą sobie osoby $\mathrm{z}$ astmą $(p<0,05)$. Sprawdzono również, czy płeć różnicuje badanych pod względem poziomu akceptacji (tab. 2) i uzyskano wyniki wskazujące na to, że w grupie chorych na astmę kobiety w mniejszym stopniu są skłonne zaakceptować trudności związane $\mathrm{z}$ chorobą $(p<0,001)$. W grupie osób z łuszczycą płeć nie różnicowała badanych pod względem stopnia akceptacji.

T a b e la 2

Poziom akceptacji choroby w grupie osób z łuszczycą i grupie chorych na astmę oraz w zależności od płci - test istotności różnic $t$-Studenta

\begin{tabular}{|c|c|c|c|c|c|c|}
\hline \multirow{3}{*}{ Chorzy ogółem } & \multicolumn{2}{|c|}{ Kobiety } & \multicolumn{2}{|c|}{ Mężczyźni } & \multirow{3}{*}{$t$} & \multirow{3}{*}{$p$} \\
\hline & \multicolumn{2}{|c|}{$N=120$} & \multicolumn{2}{|c|}{$N=112$} & & \\
\hline & $M$ & $S D$ & $M$ & $S D$ & & \\
\hline Akceptacja & 26,41 & 7,49 & 28,11 & 5,26 & $-1,98$ & 0,05 \\
\hline \multirow{2}{*}{ Chorzy na łuszczycę } & \multicolumn{2}{|c|}{$N=36$} & \multicolumn{2}{|c|}{$N=84$} & \multirow{2}{*}{$t$} & \multirow{2}{*}{$p$} \\
\hline & $M$ & $S D$ & $M$ & $S D$ & & \\
\hline Akceptacja & 26,20 & 7,13 & 26,50 & 7,67 & $-0,20$ & 0,83 \\
\hline \multirow{2}{*}{ Chorzy na astmę } & \multicolumn{2}{|c|}{$N=63$} & \multicolumn{2}{|c|}{$N=49$} & \multirow{2}{*}{$t$} & \multirow{2}{*}{$p$} \\
\hline & $M$ & $S D$ & $M$ & $S D$ & & \\
\hline Akceptacja & 26,14 & 5,16 & 30,65 & 4,22 & $-4,95$ & 0,001 \\
\hline
\end{tabular}


Kolejnym etapem było porównanie poziomu umiejscowienia kontroli zdrowia w obu grupach (tab. 3). Okazało się, że osoby z astmą silniej wierzą w to, że mogą mieć wpływ na własne zdrowie. Z kolei chorzy na łuszczycę są bardziej przekonani, że ich zdrowie zależy przede wszystkim od innych ludzi lub od przypadku czy zbiegu różnych okoliczności.

T a b e la 3

Poziom kontroli zdrowia w badanych grupach - test istotności różnic $t$-Studenta

\begin{tabular}{|l|c|c|c|c|c|c|}
\hline \multirow{2}{*}{$\begin{array}{c}\text { Umiejscowienie kontroli } \\
\text { zdrowia }\end{array}$} & $\begin{array}{c}\text { Chorzy na fuszczycę } \\
(N=120)\end{array}$ & \multicolumn{2}{c|}{$\begin{array}{c}\text { Chorzy na astmę } \\
(N=112)\end{array}$} & \multirow{2}{*}{$t$} & \multirow{2}{*}{$p$} \\
\cline { 2 - 5 } & $M$ & $S D$ & $M$ & $S D$ & & \\
\hline Kontrola wewnętrzna & 22,94 & 6,26 & 26,76 & 4,32 & $-5,36$ & 0,001 \\
\hline Wpływ innych & 26,57 & 5,30 & 20,69 & 5,30 & 8,23 & 0,001 \\
\hline Przypadek & 22,45 & 6,53 & 18,03 & 6,53 & 5,47 & 0,001 \\
\hline
\end{tabular}

Zależności między akceptacją choroby i kontrolą zdrowia oraz pozostałymi badanymi zmiennymi przedstawiono w tab. 4. W grupie chorych na łuszczycę wykazano ujemną zależność między akceptacją choroby a przekonaniem o wpływie innych ludzi na zdrowie i wiekiem. Innymi słowy, im większa wiara w to, że inni ludzie (w tym personel medyczny) mają kontrolę nad zdrowiem i im starszy wiek, tym akceptacja łuszczycy jest mniejsza. Wśród chorych na astmę $\mathrm{z}$ akceptacją wiążą się takie zmienne, jak wewnętrzne umiejscowienie kontroli zdrowia, wpływ innych, czas trwania choroby i jej ciężkość. Silniejsze przekonanie o posiadaniu wpływu na własne zdrowie ma związek z większą akceptacją, natomiast silniejsza wiara we wpływ innych ludzi, większe nasilenie astmy i starszy wiek wiążą się z mniejszym stopniem akceptacji.

T a b e l a 4

Zależności między akceptacją choroby a badanymi zmiennymi w grupie chorych na łuszczycę i w grupie chorych na astmę - współczynniki korelacji $r$-Pearsona

\begin{tabular}{|c|c|c|c|c|c|c|}
\cline { 2 - 7 } \multicolumn{1}{c|}{} & \multicolumn{8}{c|}{ Chorzy na łuszczycę } \\
\cline { 2 - 8 } \multicolumn{1}{c|}{} & $\begin{array}{c}\text { kontrola } \\
\text { wewnętrzna }\end{array}$ & $\begin{array}{c}\text { wpływ } \\
\text { innych }\end{array}$ & przypadek & $\begin{array}{c}\text { ciężkość } \\
\text { choroby }\end{array}$ & wiek & $\begin{array}{c}\text { czas trwania } \\
\text { choroby }\end{array}$ \\
\hline Akceptacja & 0,05 & $-0,26^{*}$ & $-0,12$ & 0,04 & $-0,21^{*}$ & $-0,01$ \\
\hline & $\begin{array}{c}\text { kontrola } \\
\text { wewnętrzna }\end{array}$ & $\begin{array}{c}\text { wpływ } \\
\text { innych }\end{array}$ & przypadek & $\begin{array}{c}\text { ciężkość } \\
\text { choroby }\end{array}$ & wiek & $\begin{array}{c}\text { czas trwania } \\
\text { choroby }\end{array}$ \\
\hline Akceptacja & $0,60^{*}$ & $-0,24^{*}$ & 0,02 & $-0,49^{*}$ & $-0,24^{*}$ & $-0,34^{*}$ \\
\hline
\end{tabular}

$* p<0,05$. 
Ostatnim etapem prezentowanych analiz było zidentyfikowanie determinantów akceptacji choroby w obu grupach (tab. 5). W tym celu posłużono się analizą regresji wielokrotnej (metodą krokową postępująca). Do analizy wprowadzono wszystkie badane zmienne. W niniejszym opracowaniu zaprezentowane zostaną uzyskane wyniki końcowe (ostateczny model regresji). I tak, spośród analizowanych zmiennych akceptację łuszczycy wyjaśnia jedynie kontrola zewnętrzna (tzw. wpływ innych) i tylko w niewielkim procencie (11\% zmienności wyników). Im silniejsza wiara we wpływ innych ludzi na zdrowie, tym mniejsza akceptacja łuszczycy. Akceptację astmy wyznaczają trzy zmienne kontrola wewnętrzna, czas trwania choroby i jej ciężkość (w sumie 51\% zmienności). Akceptacja choroby jest tym większa, im większe przekonanie o posiadaniu wpływu na stan zdrowia, krótszy czas choroby i mniejsze jej nasilenie.

Tabela 5

Wyznaczniki akceptacji choroby w grupie chorych na łuszczycę i w grupie chorych na astmę rezultaty krokowej regresji wielokrotnej

\begin{tabular}{|l|c|c|}
\hline \multicolumn{3}{|c|}{ Chorzy na łuszczycę } \\
\hline Zmienna & $\beta$ & $p$ \\
\hline Wpływ innych & $-0,28$ & 0,000 \\
\hline \multicolumn{3}{|c|}{$R^{2}=0,11 ; p<0,01 ; F(4,115)=2,42$} \\
\hline \multicolumn{3}{|c|}{ Chorzy na astmę } \\
\hline Zmienna & $\beta$ & $p$ \\
\hline Kontrola wewnętrzna & 0,54 & 0,000 \\
\hline Czas trwania choroby & $-0,35$ & 0,000 \\
\hline Ciężkość choroby & $-0,29$ & 0,000 \\
\hline \multicolumn{2}{|c|}{} \\
\hline
\end{tabular}

\section{Podsumowanie i dyskusja wyników}

Porównanie stopnia akceptacji choroby w grupie osób z łuszczycą i w grupie osób z astmą wykazało, że z problemami wynikającymi ze stanu zdrowia (takimi jak ograniczenia w codziennym funkcjonowaniu, poczucie braku samowystarczalności i zależności od innych) zdecydowanie lepiej radzą sobie osoby z astmą. Z kolei spośród chorych na astmę większe problemy z zaakceptowaniem swojej choroby mają kobiety. Podobne wyniki uzyskał m. in. A. Ni edzielski i in. (2007), sugerując jednakże, że kobiety generalnie mają większe trudności w zaadaptowaniu się do choroby przewlekłej. Takiej zależno- 
ści nie odnotowano jednak w odniesieniu do badanych osób z łuszczycą - płeć nie różnicowała badanych pod względem stopnia akceptacji choroby. Uzyskane wyniki wydają się w pewnym stopniu zbieżne z badaniami D. G. F o r t u n e i in. (1997), w których wykazano, że mężczyźni i kobiety z łuszczycą nie różnią się w ocenie jakości życia. Brak zależności między płcią i jakością życia potwierdził również J. D e K o r te (2004). Warto jednak podkreślić, że istnieją badania dowodzące, iż łuszczyca znacznie bardziej obniża jakość życia u kobiet niż u mężczyzn (m. in. Ste ud en, J an ow ski, 2001; P a p a d o p oulos, Wa lker, 2003; Dalgard i in., 2004; Zachariae i in., 2004; Uttjek i in., 2004).

Analiza stopnia przekonania o umiejscowieniu kontroli zdrowia wykazała, że osoby $\mathrm{z}$ astmą silniej wierzą $\mathrm{w}$ to, iż mogą mieć wpływ na własny stan fizyczny. Silniejsze przekonanie o posiadaniu wpływu na własne zdrowie wiąże się zaś z większą akceptacją astmy. Większa wiara we wpływ innych ludzi na kondycję fizyczną wiąże się zaś z mniejszym stopniem akceptacji. Na adaptacyjny wpływ przekonania o posiadaniu kontroli nad objawami astmy wskazuja również badania M. Chełmińskiej i in. (2007) oraz K. Lavoie i in. (2008).

Chorzy na łuszczycę są bardziej przekonani, że ich zdrowie zależy przede wszystkim od innych ludzi lub od przypadku czy zbiegu różnych okoliczności. Im silniejsza wiara we wpływ innych ludzi na stan fizyczny (łuszczycę), tym mniejsza jego akceptacja. Być może silna wiara w skuteczność działań personelu medycznego i otoczenia wiąże się z silniejszą koncentracją na chorobie oraz większym rozczarowaniem w przypadku nawrotów. Jest to o tyle ciekawe, że przekonanie o posiadaniu wpływu na własne zdrowie, czyli wewnętrzne umiejscowienie kontroli zdrowia, $\mathrm{z}$ akceptacją łuszczycy nie ma związku.

$\mathrm{W}$ obu badanych grupach $\mathrm{z}$ większą akceptacją choroby koreluje ujemnie wiek, zaś w grupie chorych na astmę dodatkowo ciężkość objawów.

Akceptację łuszczycy determinuje $\mathrm{w}$ niewielkim procencie jedynie przekonanie o kontroli zewnętrznej, czyli wpływie innych ludzi na zdrowie (który ma związek z mniejszą akceptacją). Akceptację astmy wyznaczają kontrola wewnętrzna, czas trwania choroby i jej ciężkość. Akceptacja choroby jest tym większa, im większe przekonanie o posiadaniu wpływu na stan zdrowia, krótszy czas choroby i mniejsze jej nasilenie.

Pozytywna rola przekonania o wpływie na własne zdrowie wydaje się zrozumiała. Uważa się, że osoby o tzw. wewnętrznym umiejscowieniu kontroli zdrowia są bardziej odpowiedzialne zarówno za swoje zdrowie, jak i za proces rehabilitacji, ponadto są bardziej autonomiczne w podejmowaniu decyzji, częściej angażują się w aktywność prozdrowotną chcą wiedzieć i wiedzą więcej o swoim stanie zdrowia oraz częściej szukają kontaktu z personelem medycznym (D rwa l, 1995; J u c zyńs ki, 2001; M a crodimitris, Endler, 2001). Tak więc wiara w posiadanie kontroli osobistej nad zdarzeniami wpływa na stan 
ludzi chorych i ich zachowania. Przykładem mogą być chorzy po zawale serca, którzy zachowywali się odmiennie wobec stosowanego leczenia w zależności od umiejscowienia kontroli. Chorzy $\mathrm{z}$ wewnętrznym umiejscowieniem kontroli lepiej współpracowali z personelem leczącym, byli mniej przygnębieni w porównaniu z pacjentami o zewnętrznym umiejscowieniu kontroli. $Z$ kolei u pacjentów chorych na nowotwory źle rokujący styl radzenia sobie $\mathrm{z}$ chorobą, zwany beznadziejno-bezradnym, połączony był z zewnętrznym umiejscowieniem kontroli (Izdebski, 1998). Wydaje się, że osoby o wewnętrznym umiejscowieniu kontroli są lepiej przygotowane do zmagania się z przeciwieństwami losu. Jak podkreśla J. Chodkiewicz (2004), osoby wierzące we własną możliwość wpływania na stresujące wydarzenia życiowe skuteczniej zmagają się z nimi. Osoby zewnętrznie umiejscawiające kontrolę pod wpływem negatywnych wydarzeń życiowych podlegają większej liczbie różnorodnych zaburzeń psychopatologicznych (,jestem jak liść na wietrze”, „to fatum”, „przekleństwo”, „przeznaczenie”). Silnia zewnątrzsterowność wzmaga poczucie bezradności i sprzyja pasywności. Wydaje się więc, że najkorzystniejsza dla funkcjonowania człowieka jest umiarkowana wewnątrzsterowność - jest bowiem faktem, że nie na wszystko w życiu mamy wpływ.

Należy jednak zaznaczyć, iż wyższość wewnętrznego umiejscowienia kontroli nad zewnętrznym, w kontekście radzenia sobie ze stresem, została podważona przez niektórych badaczy (P oprawa, 2001). Między innymi relacyjna teoria stresu dowodzi, iż przekonania o posiadaniu kontroli nad daną sytuacją mogą w pewnych warunkach wzmagać napięcie i negatywne emocje. Osoby wewnętrznie umiejscawiające kontrolę mogą w obliczu porażek odczuwać silniejsze napięcie ze względu na to, iż mają większą tendencję do przypisywania sobie odpowiedzialności za zaistniałe okoliczności. Być może to, który rodzaj lokalizacji kontroli jest bardziej pożądany, zależy od psychospołecznego kontekstu określonej sytuacji, w której znalazł się człowiek. Ogólnie mówiąc, im większe poczucie zagrożenia w danej sytuacji, tym bardziej znacząca dla jednostki może być możliwość kontroli - im ważniejsze jest dla człowieka zdarzenie, tym istotniejsza może być wiara w możliwość kontrolowania efektów.

Istnieją takie sytuacje stresowe, w których posiadanie kontroli może wręcz stres nasilać. Występuje to wtedy, kiedy koszt psychologiczny lub społeczny jest wysoki lub gdy posiadanie kontroli w takiej sytuacji jest niezgodne $\mathrm{z}$ preferowanym stylem radzenia sobie (P o p r a w a, 2001).

Sugeruje się, że zarówno nadmiar, jak i brak poczucia kontroli mogą prowadzić do negatywnych efektów emocjonalnych i przystosowawczych. Istotna wydaje się więc umiejętność elastycznego dopasowania się do wymagań sytuacji. Co więcej, okazuje się, że kontrola wewnętrzna jest predyktorem zachowań zdrowotnych, ale tylko dla tych osób, które zdrowiu przypisują wysoką wartość (J u c z yń s k i, 2001; P o p r a w a, 2001). 
W świetle prezentowanych wyników można dodać, że znaczenie rodzaju umiejscowienia kontroli zdrowia zależy od obrazu klinicznego i dynamiki choroby. Oczywiście prezentowane badania miały wiele ograniczeń - grupy chorych nie były homogeniczne, występowały wyjątkowo duże różnice w proporcjach liczebności płci, zaś metoda zastosowana do badania umiejscowienia kontroli zdrowia szacuje kontrolę zdrowia w ogóle, nie zaś przekonanie o posiadaniu wpływu na konkretną jednostkę chorobową (nie jest to metoda specyficzna). Wydaje się, że chcąc odpowiedzieć na pytanie, jaki rodzaj kontroli jest bardziej adaptacyjny w danym schorzeniu, należy również poznać przekonania na temat swojego stanu zdrowia, czyli tzw. „obraz choroby” lub poznawczą reprezentację choroby, obejmującą przyczyny, konsekwencje, tożsamość, przebieg i rokowania (L e v e n tha 1, 1980). W zależności od treści obrazu choroby należałoby zaplanować oddziaływania terapeutyczne (psychoterapeutyczne). Niemniej jednak można zaryzykować stwierdzenie, że w przypadku chorych na łuszczycę warto (skoro zewnętrzne umiejscowienie kontroli wiąże się z mniejszą akceptacja) nie tyle próbować obniżać wiarę w skuteczność leczenia, co pracować nad osłabieniem pragnienia pozbycia się zmian na skórze i nad tym, aby w mniejszym stopniu uzależniać swoje życie i życiowe wybory od wyglądu. Innymi słowy - próbować żyć (prawie) tak, jakby choroby nie było. W przypadku astmy ważne wydaje się wzmacnianie poczucia kontroli i uczenie tejże kontroli poprzez np. rozszerzenie procesu terapii astmy o elementy psychoedukacji, polegającej na zapoznawaniu chorego $\mathrm{z}$ aktualnym stanem wiedzy na temat choroby i jej leczenia oraz metodami radzenia sobie ze stresem nią spowodowanym.

\section{Bibliografia}

Acay A., Pekcanlar A., Bozdag K. E., Altintas I., Karaman A. (2002), Assessment of depression in subjects with psoriasis bulgaris and lichen planus, ,Journal of European Dermatology and Venerology", 16, 347-352.

Ad a m s R., Wakefield M., Wils on D., Parsons J., Campbell D., S m ith B., $\mathrm{R}$ uffin R. (2001), Quality of life in asthma: A comparison of community and hospital asthma patients, ,Journal of Asthma”, 38 (3), 205-214.

Chodkiewicz J. (2004), Problem akceptacji choroby u osób uzależnionych od alkoholu. Znaczenie zasobów osobistych, „Acta Universitatis Lodziensis”, Folia Psychologica 8, 123133.

Chodkiewicz J. (2005), Psychologia zdrowia. Wybrane zagadnienia, Wydawnictwo Wyższej Szkoły Humanistyczno-Ekonomicznej w Łodzi, Łódź.

Chełmińska M., Werachowska L., Niedoszytko M., Bolałek M., Szyma n o w s k a A., D a m p s-K oń s t a ń s k a I., S ł o m in s k i J., J a s s e m E. (2007), Jakość zycia chorych na astme dobrze i źle kontrolowanq, „Pneumonologia i Alergologia Polska”, 75 (1), 70-75. 
Cubała M. J., Jakuszkowiak-Wojten K., Barańska-Rybak W., Sokołows k a-W o j d y o M. (2006), Depresja w przebiegu luszczycy: opis przypadku, „Psychiatria”, 3 (3), 138-142.

D a 1 gard F., S ve n s s on A., H o 1 m J., S u nd by J. (2004), Self-reported skin morbidity among adults: associations with quality of life and general health in a Norwegian survey, „Journal of Investigative Dermatology”, 9, 120-125.

De Korte J., S prangers M. A. G., M o mbers F. M. C., B os J. D. (2004), Quality of life in patients with psoriasis: A systematic Literature Review, „The Journal of Investigative Dermatology, Symposium Proceedings", 9 (2), 140-147.

D rwa 1 R. Ł. (1995), Adaptacja kwestionariuszy osobowości. Wybrane zagadnienia i techniki, Wydawnictwo Naukowe PWN, Warszawa.

Dubertret L., Mrowietz U., Ranki A., Kerkof P. C. M. van de, Chimenti S., L o t $\mathrm{t}$ T., S $\mathrm{c}$ h a f e r G. (2006), European patient perspectives on the impact of psoriasis: the EUROPSO patient membership survey, „British Journal of Dermatology”, 1 (4), 729-736.

Fortune D. G., Ma in C. J., O' S ulliva n T. M., Griffith s C. E. M. (1997), Quality of life in patients with psoriasis: The contribution of clinical variables and psoriasis-specific stress, „British Journal of Dermatology”, 137, 755-760.

Fridri k s s o n T., P e t e r s s o n U. (1978), Severe psoriasis - oral therapy with a new method, „Dermatologica”, 157, 238-244.

G in sburg I. H. (1996), The psychosocial impact of skin disease. An overview, „Dermatology Clinics", 14 (3), 473-483.

G in sburg I. H., Link B. G. (1989), Feelings of stigmatization in patients with psoriasis, „Journal of the American Academy of Dermatology”, 20, 53-63.

I z d e b s k i P. (1998), Funkcjonowanie osób z chorobq nowotworowa po chemioterapii, WSP, Bydgoszcz.

J a bło ń s k a S., M a j e w sk i S. (2005), Choroby skóry i choroby przenoszone droga ptciowa, PZWL, Warszawa.

Jankovic S., Raznatovic M., Marinkovic J., Jankovic J., Kocev N., T o m i c-S p i r i c V., V a s i $1 \mathrm{j}$ e v i c N. (2011), High related quality of life in patients with psoriasis, „Journal of Cutaneous Medicine And Surgery”, 15 (1), 29-36.

J a n ow ski K. (2006), Osobowościowe uwarunkowania radzenia sobie ze stresem tuszczycy, Polihymnia, Lublin.

J u c z y ń s k i Z. (2001), Narzędzia stosowane w promocji i psychologii zdrowia, PTP, Warszawa.

Lavoie K., Bouchard A., Joseph M., Campbell T., Favreau H., Bacon S. (2008), Association of asthma self-efficacy to asthma control and quality of life, „Annals of Behavioral Medicine", 36, 100-106.

L e v e $\mathrm{n} t \mathrm{~h}$ a 1 H., M e y e $\mathrm{r}$ D., N e r e $\mathrm{n}$ z D. (1980), The common sense representation of illness danger, [w:] S. R a ch man (ed.), Contribution to medical psychology, Pergamon Press, Oxford, 7-30.

Ma n c u s o C. A., P e t e r s o n M., C harls o n M. E. (2000), Effects of depressive symptoms on health-related quality of life in asthma patients, „Journal of General Internal Medicine”, 15 (5), 301-310.

Ma crodi mitris S., Endler N. (2001), Coping, control, and adjustmentin type 2 diabetes, „Health Psychology”, 3, 208-216.

Mosen D., Schatz M., Gold R., Mularski R., Wong W., Bellows J. (2010), Medication use, emergency hospital care utilization, and quality-of-life outcome disparities by racelethnicity among adults with asthma, ,The American Journal of Managed Care”, 16 (11), 821-828. 
M c K e n n a K. E., S t e r n R. S. (1997), The impact of psoriasis on the quality of life of patients from the 16-center PUVA follow up cohort, „Journal of The American Academy of Dermatology", 36, 388-394.

Niedzi e $1 \mathrm{sk}$ i A., H u m e n i u k E., B ła zi a k P., F e d or u k D. (2007), Stopień akceptacji choroby w wybranych chorobach przewlektych, „Wiadomości Lekarskie”, LX (5-6), 224227.

$\mathrm{Oh}$ E. (2008), The relationship between disease control, symptom distress, functioning, and quality of life in adults with asthma, „The Journal of Asthma: Official Journal of The Association for the Care of Asthma”, 45 (10), 882-886.

Pacan P., Szepietowski J., Kiejna A. (2002), Wplyw czynników psychicznych na przebieg tuszczycy, „Przegląd Dermatologiczny”, 89, 401-407.

Papadopoulos L., Walker C. (2003), Personality, Coping and Sex as Psychosocial Aspects of Psoriatic Arthropathy, „Dermatology + Psychosomatics”, 4, 27-32.

Poprawa R. (2001), Zasoby osobiste $w$ radzeniu sobie ze stresem, [w:] G. DolińskaZ y g m u n t (red.), Elementy psychologii zdrowia, Wydawnictwo UW, Wrocław, 103-141.

P otoczek A. (2010), Wspótwystępowanie astmy aspirynowej, zespolu lęku napadowego $i$ depresji a płeć chorych $i$ doznane urazy psychiczne, „Psychiatria Polska”, XLIV (4), $557-567$.

Roenigk R. K., Roenigk H. H. (1979), Sex differences in the psychological effects of psoriasis, „Cutis”, 21, 529-553.

Scharloo M., Kapte in A. A., We in man J., B ergman W., Vermeer B. J., R o o i j m an s H. G. M. (2000), Patient's illness perceptions and coping as predictors of functional status in psoriasis: a 1-year follow-up, „British Journal of Dermatology”, 142, 899-907.

St e uden S. (2002), Z psychologicznej problematyki zdrowia i choroby, [w:] P. Ole ś, S. S t e u d e n, J. T o c z y dło w sk i (red.), Jak świata mniej widzę. Zaburzenia widzenia a jakość życia, Towarzystwo Naukowe KUL, Lublin, 27-36.

Steuden S., Janowski K. (2001), Zastosowanie kwestionariusza Skindex do pomiaru jakości życia u pacjentów z luszczyca, ,Przegląd Dermatologiczny”, 88 (1), 41-48.

Szumański J., Kokoszka A. (2001), Czynniki psychiczne w tuszczycy - przeglad piśmiennictwa, „Psychiatria Polska”, 35 (5), 831-838.

Światowa strategia rozpoznawania, leczenia i prewencji astmy (2002), NHLBI/WHO raport.

U t t j e k M., D u fa k e r M., N y g r e n L., S t e n b e rg B. (2004), Determinants of quality of life in a psoriasis population in Northern Sweden, "Acta Dermatol-Venerologica", 84, $37-43$.

Zachariae R., Zachariae H., Ibsen H. H. W., Mortensen J. T., Wulf H. C. (2004), Psychological Symptoms and Quality of Life of Dermatology Outpatients and Hospitalized Dermatology Patients, „Acta Dermatol-Venerologica”, 84, 205-212.

Joanna Miniszewska, Joanna Paul-Kańska, Anna Zalewska-Janowska

\section{Acceptance of chronic somatic diseases (psoriasis and asthma). Whether the belief about having impact on own health always help?}

The aim of this study was to assess the level of acceptance of two selected chronic conditions, different in terms of the clinical picture - asthma and psoriasis and to define the role of belief in the possession of the impact on their health in adapting to illness. Studies also included 
medical and demographic variables. The following methods were used: Acceptance Illness Scale (B. Felton, T. Revenson, G. Hinrichsen, Polish adaptation: Z. J u c z yński (2001)), The Multidimensional Health Locus of Control Scale MHLC (K. Wallston, B. Wallston, R. Devellis, Polish adaptation: Z. Juczyński (2001)), PASI Scale to measure the severity of psoriasis (Fridriksson, Petersson, 1978). The severity of asthma was assessed by a specialist pulmonologist on the basis of classification of internal medicine NHLB/NAEPP. 112 patients with asthma and 120 patients with psoriasis participated in this study. It turned out that the treatment groups differ in level of acceptance of the disease. In both groups, the acceptance of illness linked to other dimensions of health locus of control, the constellations of different variables determine the acceptance of asthma and psoriasis.

Keywords: illness acceptance, health locus of control, psoriasis, asthma (akceptacja choroby, umiejscowienie kontroli zdrowia, łuszczyca, astma). 